\title{
RELATIONSHIP OF THE QURAN AND OTHER RELIGIOUS SCRIPTURES: Studies on al-Muhaymin in Q.S. al-Mâidah 48
}

\section{Fuji $\mathcal{N u r}$ Iman}

Universitas Islam Negeri Sunan Kalijaga Yogyakarta, Indonesia e-mail: fujinuriman03@gmail.com

\section{Abstract}

This paper reviews the position of the Quran as al-Muhaymin toward the other religious scriptures. Specifically, the study focuses on Q.S. al-Mâidah [5]: 48, which explicitly contains the word "al-muhaymin". That word in the mentioned surah triggers the polemics among mufassir and starts the discussion on its relation with the authenticity of the other previous holy books. Some relate the books' authenticity with naskh and tahrîf that leads to the claim of falsification within those books. By interpreting the word "al-muhaymin", the author attempts to objectively re-comprehend the bond between the Quran and the previous holy books. By tracing the classic and modern tafsîr books, the author assumes that the Quran is the continuation of other books revealed by Allah in advance. The connection of the Quran and the previous books is as the sharia revealed by Allah to people with the similar universal principles. In this case, God and the principles within those books are the same, yet, it is formulated by the law which is dissimilar in the context. Both the Quran and the previous holy books have the same purpose that is to assure people's safety and happiness.

Tulisan ini mengulas posisi Al-Qur'an sebagai al-Muhaymin terhadap kitab-kitab suci agama lain. Secara khusus, tulisan ini difokuskan pada 
Q.S. al-Mâidah [5]: 48 yang secara eksplisit memuat kata "almuhaymin". Kata al-muhaymin dalam ayat tersebut menuai polemik di antara mufassir sekaligus relasinya dengan otentisitas kitab-kitab suci sebelumnya. Banyak kalangan yang mengaitkan otentisitas kitab-kitab terdahulu dengan naskh dan tahrîf, sehingga berujung pada adanya klaim pemalsuan dalam kitab-kitab tersebut. Berbekal interpretasi terhadap kata al-muhaymin, penulis berupaya memahami kembali hubungan Al-Qur'an dengan kitab-kitab sebelumnya secara objektif. Dengan menelusuri kitabkitab tafsir klasik dan modern, penulis menyimpulkan bahwa Al-Qur'an adalah perpanjangan dari kitab-kitab yang diturunkan Allah sebelumnya. Hubungan Al-Qur'an dan kitab-kitab sebelumnya adalah sebagai syari'at yang Allah wahyukan kepada umat manusia dengan prinsip-prinsip universal yang sama. Dalam hal ini, Tuhan dan prinsip yang ada di dalamnya sama, namun diformulasikan dengan hukum yang berbeda dalam konteksnya. Baik Al-Qur'an maupun kitab-kitab terdahulu memiliki tujuan yang sama, yakni menjamin keselamatan dan kebahagiaan manusia.

Keywords: al-Mâidah 48; Muhaymin; Quran; religious scriptures

Received: January 21, 2020; Accepted: June 26, 2020

\section{Introduction}

Around 571 AD, when Muhammad was in a state of anxiety, doubt, and hope for the truth in a cave, he received his first revelation, Q.S. al'Alaq [96]: 1-5 (Hitti 2013, 141) and was gradually dropped the other verses into a scripture as a guide to the Muslims. According to al-Zarqânî, there is difference among scholars about which verse was last revealed completely. The verses that become their topic debate are Q.S. al-Baqarah [2]: 281, Q.S. al-Baqarah [2]: 278, Q.S. al-Baqarah [2]: 282, Q.S. Âli 'Imrân [3]: 195, Q.S. al-Nisâ' [4]: 93, Q.S. al-Nisâ [4]: 176, the last verse of al-Mâidah, Q.S. alKahf [18]: 110, and Q.S. al-Naṣr [110]: 1 (al-Zarqânî 2002, 97). In the framework of the religion's holy book, apart from the Quran, which is believed coming from Muslims' God, al-Shahrastânî in his book al-Milal wa al-Nihal divide the groups into two based on the law they believe in. The first group is those who actually have holy books like the Torah and the Bible - in Quran, they are called Ahl al-Kitâb, while the second group is 
those who have similar scriptures such as the Majus and Manu people (alShahrastânî 2006, 189).

The Quran as the ultimate holy book revealed by Allah indeed has collected all the main messages contained in the previous books (Aziz 2015, 110). In addition, it should be noted that the Quran also presents itself as a musaddiq and muhaymin to the previous ones. In Fred M. Donner's language, although he does not refer to specific verses in the Quran, he argues that things closely related to Muhammad's writing are the emphasis on the Quran itself, the Arabic-language revelation, which the Muslims now assume that its status is higher than the previous books i.e. the Torah and the Gospel (Donner 2015, 230). In al-Mâidah [5] verse 48 for example, it is explicitly stated that the Quran as musaddiq and muhaymin for the books that had been previously revealed. The word Muhaymin is often emphasized with the word guarding (Departemen Agama Republik Indonesia 2009, 116; al-Adib 2013, 203). The word musaddiq as the derivations of the word al-sidq following the wazan saddaqa is often translated into justify (Firdaus 2015, 115). Nurcholish Madjid argues that the explanation of the Quran as a justifier (musaddiq), determinant and/or examiner (muhaymin), besides being a corrector (furqân) is a function of the prophet Muhammad that is to authorize the greatness of the holy books and the teachings of the previous Prophets and Apostles (Madjid 2005, 23).

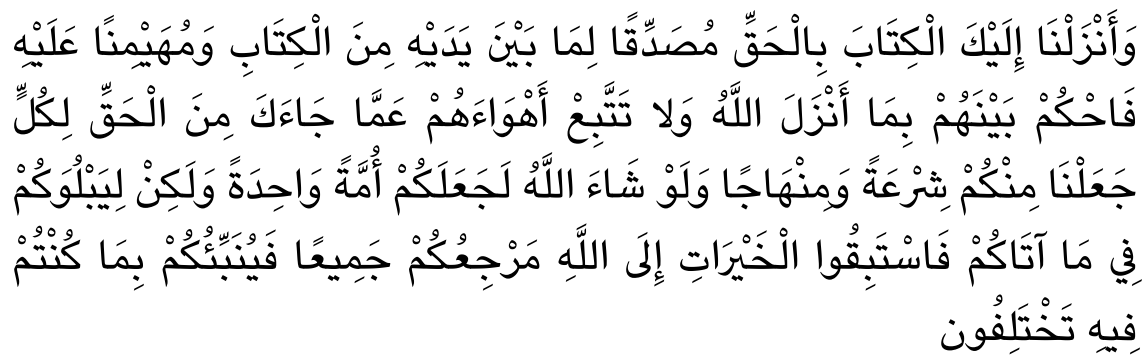

"And We have revealed to you, [O Muhammad], the Book in truth, confirming that which preceded it of the Scripture and as a criterion over it. So judge between them by what Allah has revealed and do not follow their inclinations away from what has come to you of the truth. To each of you We prescribed a law and a method. Had Allah willed, He would have made you one nation [united in religion], but [He intended] to test you in what He has given you; so race to [all that is] good. To Allah is your return all together, and He will [then] inform you concerning that over which you used to differ" Q.S. al-Mâidah [5]: 48. 
Ibn 'Abbâs, Ibn 'Ațiyah, 'Ikrimah, Ibn Jâbir, and Ibn Jarîr argue that muhayminan 'alayh in Q.S. al-Mâidah [5] verse 48 means that the Quran becomes a witness for the existence of the earlier books. Based on their scriptures, Ahl al-Kitâb had informed the news which is in line with what was written in the Quran. In addition, Qatâdah and the Muqâtil also interpreted that muhayminan 'alayh is a justification for what the previous holy books said (al-Ghurnâtî 2010, vol. 3, 512). Ibn Kathîr mentions that some mufassir such as Ibn 'Abbâs, Mujâhid, and Qatâdah explains that the muhayminan 'alayh in Q.S. al-Mâidah [5]: 48 means that the Quran testifies the earlier scriptures (Ibn Kathîr 2000, vol. 3, 236).

However, recently, the issue of naskh on the holy books and religion revealed to the earlier prophets has come to surface. According to Muhammad 'Abd al-Muta'âl al-Jabrî, Q.S. al-Baqarah [2] verse 106 is a reference used by the Islamic sharia for canceling the sharia revealed to preIslamic prophets (Affandy 2015, 110). Darwis Abu Ubaidah interpreted the

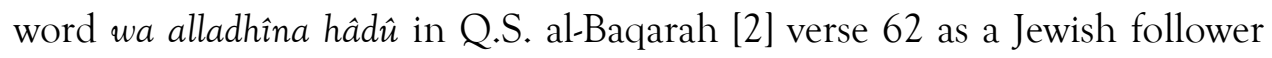
of Mûsâ who based the law on the Torah, while the word wa annașârâ in the same verse is interpreted as a Christian follower of Jesus who based the law on the Bible. He gives further explanation that the verse was not to justify the beliefs of the Jews and the present Nasârâ because they did not acknowledge Muhammad's prophecies and did not follow the path of the Muhammad believers (Ubaidah 2012, 91, 95, and 97). In addition, Shaykh Taqî al-Dîn al-Nabhânî also said that the sentence of muhayminan 'alayh in Q.S. al-Mâidah [5] verse 48, as quoted by Rohmat S. Labib, is the Quran mastery on the previous books, in other words, it abrogates (invalidate) the previous sharia (An-Nabhani 2007, 74; Labib 2013, 403).

Instead of maintaining harmony between Semitic religions, the issue about abrogation (naskh) toward previous books and religions have brought back an exclusive stigma in religious life. At the same time, previous books and religions are no longer recognized. In fact, in the context of modern religious life, pluralism is a necessity. For this reason, this paper will revive the relationship between the previous books and the Quran for several reasons. First, in the context of a pluralistic modern life, this study will provide a view of the previous holy books as the law of other religions. Second, the study gives a comprehensive view of the previous books' existence and their adherents in a group of monotheistic religions. 
The theme about relationship of the Quran and the earlier books is not a novel idea. Mun'im Sirry in his work conducted an academic study on the clarification of earlier books. The four verses becoming the focus in his study are Q.S. al-Baqarah [2]: 75, Q.S. al-Nisâ' [4]: 46, and Q.S. al-Mâidah [5]: 13 and 41 (Sirry 2013, 168-70). Sa'dullah Affandy conducted a study on the issue of intra and extra Quranic naskh by commenting on Q.S. alMâidah [5]: 48 (Affandy 2015). Other studies in general have tried to investigate questions related to earlier books, for instance, Tasirun Sulaiman in Al-Qur'an Berbicara Agama Lain: Sisi Keterbukaan Kitab Suci Umat Islam (Sulaiman 2011). In addition, there are other works in the form of scientific journals e.g. Hamdani Anwar's Tahrif dalam Al-Qur'an: Studi Analitis tentang Perubahan yang Bersifat Lafdzy dan Ma'nawy (Anwar 2016).

Based on the searched key words of the Quran in the sense of being the last holy book, religious scriptures, and its relationship with other scriptures, the author found several writings. First, related to the Quran as the last holy book, Lasmana and Suhendra wrote the Quran and three other religious scriptures. They raised the issue of how to embrace the Quran and other Samawî books (Lasmana and Suhendra 2017). They discussed the variety and definition of the holy books. Their study showed that the holy book is a kalâm Allâh that was revealed to the messenger of Allah SWT and that the Quran is not the only holy book. There are Psalms, the Torah, the Gospel, and Suhuf Ibrâhîm. To believe in these books is a must. The changes and deviations contained in the previous books are out of what should Muslims believe. The Quran as the last holy book aims at covering the previous books. Its content is universal for all mankinds (Lasmana and Suhendra 2017, 51).

The second keyword is the Quran as religious scripture. Through his writing, Halim discussed the terms related to Jewish including history, doctrine, rituals, religious experience, and Jewish institution (Halim 2017) . He also presented the source of Jewish's religious ideas, namely Tanakh, Talmud Midrash, Halakhah, and Aggadah (Halim 2017, 136). In reviewing Judaism's holy book, Halim only focused on social and religious history without relating to other holy books or beliefs. Furthermore, there is also Amaliyah discussing about Jewish, Christian, and Islam's holy books. She presented the essence of those books and the cold war among the three religions in Jerusalem (Amaliyah 2017). 
The third keyword is the Quran and other religious scriptures. In her last-year study, Mukzizatin raised issues related to how the Quran sees the interaction between Muslims and non-Muslims as well as clear positions and boundaries related to behavior among religious communities (Mukzizatin 2019). She presented a discussion related to the concept of tolerance between religious communities in the Quran, the Indonesian paradigm of harmonious religious relation, and the ideal conditions among religious communities. Her study result revealed that the m'Îsâpplication of tolerance can be the cause of harmful conflict so Muslims are highly suggested to be the pioneer to improve positive attitude (Mukzizatin 2019, 178).

From the previous studies, this recent study will deal with the questions of definitions and naskhs in earlier books. This relational text of the Quran and other religious scriptures will specifically refer to the Quran as al-Muhaymin over the previous book. At the same time, the other ancient scriptures are also considered religious books. Therefore, this study will comment on the position of the Quran as al-Muhaymin as this is argued by scholars who have come to understand the meaning and shed light on the relation of the Quran and other religious scriptures.

\section{About Q.S. al-Mâidah [5]: 48}

Surah al-Mâidah is also called Surah al'Uqûd. According to Muhammad al-Ghazâlî, the latter name is more in line with the theme of this surah, while the first one refers more to the request of Hawwâriyyun to 'Îsâ (PBUH) to send them food from heaven as a meal and a good news. Even so, God eventually granted the request to strengthen 'Îsâ's prophecy and to justify his treatise (Al-Ghazali 2004, 127). The next name of AlMâidah is al-akhyâr (good people) because those who fulfill their promise must be good people. Another name is al-munqidhah (savior). It is narrated that the Prophet (PBUH) says: "Surah al-Mâidah is called malakût al-samâwât (the highest kingdom of Allah) in the name of al-munqidhah because it saves its readers and practitioners from the tormenting angels" (Shihab 2011, vol. $3,3)$.

According to Maḥmud Shaltût, surah al-Mâidah explained the general condition of the revelation time and also Muslims' condition at that specific time (Syaltut 1999, 507). He adds that the characteristics of surah al-Mâidah are scarcely found in other Madaniyah surah which speak about 
shirk and mushrik. According to him, mushrik's period has ended and they no longer played any role. Muslims needed the improvement of tasyrî̀ and politics to govern their affairs and guaranteed the survival of their happiness and leadership. They also had special relationship with various groups of Ahl al-Kitâb living under their shade and responsibility. Therefore, the topic of the talk is all about religion and scriptures (Syaltut 1999, 511).

The aforementioned verse talks about the Quran revealed to the Prophet Muhammad (PBUH). This is after the talk of the Torah revealed to Mûsâ and the Bible revealed to 'Îsâ (Shihab 2011, vol. 3, 136). This verse was revealed after Surah al-Mumtahanah, precisely on the events of the Treaty of Hudaybiyah (Affandy 2015, 192). Based on the chronology of Ibn 'Abbâs' history, al-Kâfî, 'Ikrimah and al-Hasan, Surah al-Mâidah is in the order of 27 out of 28 surah categorized in Madaniyah (Amal 2013, 96). One of content of the Treaty of Hudaybiyah is the choice for all tribes to either follow the Prophet Muhammad or the Quraysh (al-A'zami 2005, 33).

Some points in that the Treaty of Hudaybiyah were successfully agreed without the amendment of the Prophet Muhammad were: first, that year (that specific moment) Muhammad and his companions must return to Medina, cancelled their intention to perform pilgrimage, and reassigned in the following year; second, for next year Muhammad and his entourage were allowed to enter Mecca but only for three days. The only equipment and weapon allowed to bring was covered sword; third, anyone from the Arabs who wanted to ally with Muhammad or the Quraysh should be allowed; fourth, the Quraysh people who wanted to come to Medina without their guardian's concern had to return. On the contrary, when Muslims of Medina want to return to Mecca, it must be tolerated; fifth, no war between Quraysh and Muslims for 10 years (Haif 2004, 126-8). This verse was passed down to the Prophet to decide the matter of justice filed by Ahl al-Kitâb and non-Muslims who demanded the arbitration of the Prophet to be decided on the basis of the Quran. By revealing that verse, the Prophet explained that the diversity of sharia to all people is in accordance with the different period's condition and situations, while in the time of Prophet Muhammad, Allah established Quranic based sharia (Affandy 2015, 19).

In general, as said by al-Marâghî, the verse is an indication of the diversity of sharia after previously revealing the Torah and the Gospel to Bani Israel (al-Marâghî 1946, vol. 6, 129). The verse is also often quoted by some communities to support the argument that God never lead people in 
one single sharia. Allah explained that sharia was made as a mean to compete in good deeds so that people will be rewarded according to their deeds.

Ṭabâtabâ'î commented on this verse by saying, "Verily Allah tells His servants to worship for one religion, which is to submit to Him. but to achieve that, Allah gives different ways and makes various kinds of sunnahs for His servants according to their differences in readiness and diversity" (Affandy 2015, 193). According to Muhammad Hassan Khalîl, this verse is often used by pluralism soteriology as reference for showing that God never intended to lead people to become one people with one single law (Khalil 2016, 12). In line with Khalîl, Abd. Moqsith Ghazali argues that the verse shows the diversity of the paths Allah gave to humans (Ghazali 2009, 166). Meanwhile, according to Mun'im Sirry, the verse seems to be the Quran's acknowledgment on the differences in each religion such as rituals, customs, and their own traditions (Sirry 2013, 109). Furthermore, this verse according to some opinions also becomes the point of plurality teaching of the Quran, which is considered by many to be very unique (Madjid 2005, 21). In the point of view of al-Qurțubî, Allah made various sharia to test human faith (al-Qurțubî n.d., vol. 3, 526).

Another view stated by Sayyid Qutb that the verse is actually an affirmation of Islam's message as the ultimate sharia which naturally rejects all forms of jâhiliyyah (ignorance) laws. Qutb explained that Muhammad's treatise was the sharia prepared for all mankinds, which was always applied to human life until the end of time (Affandy 2015, 195). This should be outlined that Q.S. al-Mâidah [5]: 48 does not only talk about the nature of the Quran as al-Muhaymin. More than that, the verse is also often understood that God never intended to lead people to a single sharia. Besides, it is a medium for Allah to order people to vying in doing good deeds.

\section{Quran and Other Religious Scriptures}

A few centuries after the commissioning of Ibrâhîm as a prophet with his prophetic mission and leaving only stories through spoken language, the world began to lose, borrowing the term of Jan Romein 'crisis of faith'. He argues that the world has once experienced a crisis of confidence. Then, there came number of people trying to overcome the crisis. The results showed that there was the emergence of new morality among people in the world e.g. in the region of Huang Ho and Yang Tse 
Kiang in China, the teaching of Confucius and Lao Tse was well-accepted; in the subcontinent India, Sidharta Gautama brought Buddhism on the banks of the Ganges River; in Persia, there was Zarathustra; and on the banks of the Nile, Fir'aun was born (Ghazali 2009, 422). Long after that time, among the established beliefs, there were Jews and Christians around $571 \mathrm{CE}$. Then, just as Muhammad was overcoming his anxiety, doubt, and hope for the truth, in the cave of Hira, he received his first revelation namely Q.S. al-Alaq [96]: 1-5 and gradually other verses were also revealed in turn that it then became a holy book as a guide for Muslims or later better known as the Quran.

Suhuf Ibrâhîm is believed to be one of God's revelations delivered to His prophet Ibrâhîm. Prophet Ibrâhîm or Abraham (in the Jewish tradition) himself was estimated to be born in 2166 BC (Ghazali 2009, 121). He was from the land of Ur, which was part of an ancient country that was in the region of ancient Mesopotamia (between the Euphrates and Tignis rivers) (Makin 2016, 111). In the Semitic religious environment, the Prophet Ibrâhîm was a central figure. The teachings he brought were the origins, even the foundations, of Judaism, Christianity, and Islam (Ghazali 2009, 121). While in the Islamic tradition, Ibrâhîm is believed to be not only a prophet and preacher of God's revelation, but also a tenacious Father of Monotheism and is believed to have received a holy book from God which in the Quran is called as "Suhưf Ibrâhîm" (Q.S. al-A'lâ [87]: 19) (Ghazali 2009, 122).

Abd. Moqsith Ghazali referring to the book al-Jâmi' al-Ahkâm alQur'ân by al-Qurtubî based on Abû Dhar said that the book revealed to the Prophet Ibrâhîm (Suhuf Ibrâhîm) contains tamthîl (imagery) in both worldly life and afterlife (Ghazali 2009, 122). The similar news came from Rusydi alBadrawi based on the hadith delivered by Abû Dhar that Muhammad (PBUH) said Ibrâhîm accepted ten Suhuf containing faith in God, orders for humans to manage their life and interactions with others, orders to better their morals, orders to establish an ideal family such as the obligation to treat parents well, be gentle towards the spouse, and educating children well. Sharia wise, Suhuf Ibrâhîm contains the laws e.g. the prohibition of stealing, usury, adultery, killing, inheritance law, sanctions for violators, and the necessity of caring for poor people (Harahap 2013, 85-86).

Besides the Suhuf revealed to the Prophet Ibrâhîm, the word Suhuf in the Quran also refers to a news passed down to Mûsâ which is explicitly 
mentioned in Q.S. al-A'lâ [87]: 19. In addition, the Quran also provides information about the earlier samawî scriptures for example, surah alBaqarah [2]: 87 mentions that God had brought the Torah to Mûsâ and in surah Âli 'Imrân [3]: 3 provides information about the Torah and the Bible which were revealed before the Quran.

Ahmad Musțafâ al-Marâghî said that the word Tawrah (Torah) comes from the Hebrew language. It can be meant as sharia consisting of five books, which was said that the Prophet Mûsâ was the author, namely the Book of Genesis, the Book of Exodus, the Book of Lawiyin/Leviticus, the Book of Numbers, and the Book of Tathniyat al-Ishtirâ/Deuteronomy (al-Marâghî 2003, 163). Although the Quran does not provide detail information about the Torah, the verses have explicitly provided reports that there are other mentioned books that are truly recognized and become the guidelines for the Jews with their Torah and Christianity with their Gospels before the descent of the Quran.

Besides acknowledging the existence of books revealed before the treatise came to Muhammad (PBUH), the Quran also mentions that there were changes (distortions) made by some people from the Jews and Christians to their own books. In Q.S. Âli 'Imrân [3]: 78 for example, reported that they had rolled their tongue when reading the Bible. Q.S. alBaqarah [2]: 79 also reported explicitly that there are people creating their own Bible for benefits.

Ibn Hazm states the entire Quran is something that has been proven true. His opinion was directed to Judaism and Christianity who had done tabdîl (erroneous changes) to the contents of their own holy books to cover or bury the original information written in the authentic version (Zuhri 2003, 142). Amid the tabdîl done by people to the holy books, the Quran alluded the existence of justification (Musaddiquin) of the previous books after several changed verses. These verses can at least be found explicitly in Q.S. Âli 'Imrân [3]: 3, and al Mâidah [5]: 46 and 48. It is said that of all surah in the Quran, Surah al-Mâidah was revealed the latest. Therefore, it is strongly possible that the two verses that mention the Quran as a Musaddiq to the ancient scriptures came down after the verses stating that there has been a distortion in the previously revealed holy books (al-Zuhaylî n.d., 107).

The evidence that said Muhammad (PBUH) as the last prophet and apostle is written in the Quran as well as his teaching on the abolition of 
tabbani practice (raising a child and then acknowledging him/her as one's own child, as if having a close relationship (blood-line) with the adoptive parent with all the consequences) (Madjid 2005, 21). Meanwhile, Muhammad was appointed to be the Prophet that confirms the greatness of the previous Prophets as well as their scriptures and teachings. It is inferred from the explanation of the Quran's position as the justification (musaddiq), the determinant (muhaymin), and the correction (furqân) of the deviations of the previous books' followers (Madjid 2005, 23).

Another debate when the Quran pertains the existence of previous books is about distortion (tahriff). Some verses affirm and confirm the truth of the previous scriptures, while some others suspect its status as the holy ones (Sirry 2013, 167-8). Myths about the previous books which then make their validity in doubt include naskh and tahrîf. The myth about naskh himself theoretically is never released from the Q.S. al-Baqarah [2]: 162. While the issue regarding the existence of tahriff, some verses do discuss the existence of allegations of counterfeiting against the original version of previous books. The words yuharrifûna (they change) appear four times in the Quran i.e. Q.S. al-Baqarah [2]: 75, Q.S. al-Nisâ' [4]: 46, Q.S. al-Mâidah [5]: 13, and Q.S. al-Mâidah [5]: 41 (Sirry 2013, 168-70). However, scholars have some differences in interpreting the word tahrîf. In general, they are divided into two; some say tahrîf occurs in the text, meanwhile others think tahrif is only on the understanding and interpretation yet their texts remain authentic.

Scholars' opinion differ about what verses refer to the theme of fabrication. Franst Buhl underlines the verses containing the word harrafa (Q.S. al-Baqarah [2]: 75; Q.S. al-Nisâ' [4]: 46; Q.S. al-Mâidah [5]: 13; and alMâidah [5]: 41), lawâ (Q.S. Q.S. Âli 'Imrân [3]: 78 and Q.S. al-Nisâ' [4]: 46), and baddala (Q.S. al-Baqarah [2]: 59 and Q.S. al-An'âm [7]: 162). John Wansbrough identified three concepts, namely: kitmân (concealment in Q.S. al-Baqarah [2]: 42), tabdîl (substitution in Q.S. al-Baqarah [2]: 58), and tahrîf (alteration in Q.S. al-Baqarah [2]: 75) (Sirry 2013, 166).

\section{Quran as al-Muhaymin}

Translating the word al-muhaymin with "benchmark/tolak ukur" is not accurate entirely (Shihab 2011, vol. 3, 138). According to al-Tabarî, the word is taken from al-haymanati which means al-hifz (guarding) and al-irtiqâb (watching). He adds, the word can also mean witnessing something (al- 
TTabarî 2001, vol. 4, 486). Meanwhile, according to M. Quraish Shihab, the word is taken from the word haymana which means power, supervision, and authority over something (Shihab 2011, vol. 3, 138). Sayyid Muhammad Rashîd Ridâ states the word means to be the guardian and witness of alKitâb al-Ilâhiyyah (the divine book) (Riḍa 2005, vol. 6, 240).

In line with al-Tabarî, Fakhr al-Dîn al-Râzî also presented opinion of Imâm Khalîl and Abû 'Ubaydah arguing that the meaning of the word was like a man guarding something (al-Râzî 1999, vol. 12, 371). Another opinion by al-Ṭ̂sî, the origin of the word muhaymin is "muayminan" which is agreed by al-Samarqandî (al-Samarqandî 1993, vol. 1, 441).

The scholars differ in interpreting the mentioned word in Q.S. alMâidah [5]: 48. Al-T abarî explains that there are some opinions about the position of the Quran as muhaymin. The first opinion is those defining its position in the sense of being witnesses (shahîd) of the ancient scriptures. Ibn 'Abbâs and al-Sadî are the two predecessors of al-Ṭabarî who had that opinion (al-Tabarî, 2001, vol. 4, 486). Al-Riwâyat with similar interpretation is also narrated by Nasîr al-Dîn al-Tûsî in his tafsir book of al-Tibyân fî Tafsîr al-Qur'ân. Al-Ṭ̂sî does not mention the name of al-Sadî but al-Hasan, Qatâdah, and Mujâhid (al-Ṭûsî n.d., vol. 3, 543). Jalâl al-Dîn al-Maḥallî and Jalâl al-Dîn al-Suyûtî also interpret the word muhaymin in Q.S. al-Mâidah [5]: 48 with similar interpretation (al-Mahallî and al-Suyûțî n.d., 102).

Rashîd Rị̂a gives a good question in his interpretation of the meaning of muhaymin in the sense of being a witness (shahîdan). He asks "Is it possible to decide on what the muhaymin witnessed or is it compulsory to return to the law contained in the previous book and to its members because it clarifies the testimony of the ancient book and its followers?". According to him, the expressions in Q.S. Âli "Imrân [3]: 23 can be the answer to that question. He says, the verse mentions that they are fabricating the Torah and the Gospel (Riḍâ 2005, vol. 6, 341).

The second opinion expressed by al-Tabarî is that those saying the Quran as muhaymin in the sense not only as a witness, but as aminun 'alayhi (who believe in the previous books). Those who think so are Ibn 'Abbas and Sa'îd ibn Jubayr. Al-Tabarî presents several narrations of interpretation with different links that lead to Ibn 'Abbâs and Sa'îd ibn Jubayr (al-Ṭabarî 2001, vol. 4, 486-9).

The existence of the previous books is recognized by the Quran in this sense. It does not deny that the prophets before Muhammad received 
revelation. The Quran actually confirms that the earlier prophets i.e. Prophet Mûsâ, Prophet Dâud, and Prophet 'Îsâ, also received revelations similar to Muhammad. Imâm al-Nasafî as quoted by Shaykh Ahmad ibn Hijazî al-Fishanî said that the total number of all books sent down from heaven to earth was 104 holy pages: 60 for the Prophet Shis, 3 for the Prophet Ibrâhîm, 10 for the Prophet Mûsâ before receiving the Torah, the Book of Zabur for the Prophet Dâud, the Gospel for the Prophet 'Îsâ, and the Quran for the Prophet Muhammad (Aziz 2015, 11).

Al-Tabarî -as quoted by Sa'dullah Affandi - states that Q.S. alMâidah [5]: 48 can be clearly understood that each person has different rules and traditions. Just as the Torah sets its own law, so does the Bible. In those books, God justifies what He wills and also bans what He wills. The purpose is to know who obeys Him and who does not. However, the "aldîn" He receives is the conviction of the One God taught by His prophets (Affandy 2015, 192).

The third opinion offered by al-Ṭabarî is those who consider the position of the Quran as muhaymin in the sense of musaddiq. Al-Tabarî has a riwâyat of interpretation in that sense from Yûnus, and he got from Ibn Wahab and ends with Ibn Zayd. Ibn Zayd argues that muhayminan 'alayh in Q.S. al-Mâidah [5]: 48 means musaddiqan 'alayh.

In line with Ibn Zayd, the same opinion was expressed by al-Tha'labî (al-Tha'labî 1997, vol. 2, 390). The word musaddiq as isim fâ'il in the Quran is repeated at least 19 times (Firdaus 2015, 116). Al-Ṭabarî himself acknowledges the position of the Quran as musaddiq in Q.S. al-Nisâ' [4]: 48 in the sense that Allah Almighty revealed it to justify the previous books (alṬabarî 2001, vol. 4, 567). In another verse namely Q.S. al-Mâidah [4]: 46, speaking about the Torah and the Gospel, al-Ṭabari also interpreted the Quran as a muhaymin on earlier books in the sense that the function of the Quran was passed down to Muhammad (PBUH) to justify the earlier books given to the ancient prophets.

\section{The Relationship of the Quran and Other Religious Scriptures}

One of the conceptions that God has contributed to human's life is reflected in the existence of religious scriptures. In the historical record we at least know a few holy books becoming the basis of its followers i.e. The Torah or what came to be known as the Old Testament as the Jewish holy book, the Gospel as the Christian holy book, and the Quran as Muslims' 
holy book. While in the Quran, some of God's messages delivered to humans include Ibrâhîm receiving Suhuf, Mûsâ receiving the Torah, Daud with Zabur, 'Îsâ with his Gospel, and Muhammad receiving the Quran. However, only the Torah, the Gospel and the Quran which later became the three holy books which were adhered by the followers of the world's largest religions namely Judaism, Christianity, and Islam.

As a holy book adheres to religions other than those brought by Muhammad, myths about the previous books which validity is in doubt include naskh and tahriff. The myth about naskh theoretically is never released from the Q.S. al-Baqarah [2]: 162. Naskh or abrogation theory is often used to compromise Quranic verses that seem contradictory. The scholars themselves differ in opinion about what is meant by naskh. AlShâfi'î (d. $204 \mathrm{H})$ defines it as abandoning the obligation of the law. Meanwhile, according to Abû Manșûr al-Baghdadî, naskh is the disappearance of the law by moving away from that law. Ibn Hazm (d. 456 $\mathrm{H}$ ) defines naskh in the broader sense as removing the law after it is established, explaining the boundaries of the worship period, and revoking certain worship that was previously applicable.

While the issue of the existence of tahriff, several Quranic verses indeed mention the existence of accusations of counterfeiting or in the term of the Koran "tahriff" of the earlier books. However, ulama disagree on the meaning of the word tahriff. In general, ulama are divided into two. Some say tahrif takes place in the scriptures, meanwhile some think that tahrif only involves understanding and interpretation but their texts remain authentic. The Quranic term surrounding the accusation of forgery which is widely discussed is "tahrîf" which is a verb from "harafa" (Sirry 2013, 170). A Syriac mufassir, Jamâl al-Dîn al-Qasîmî understands the verses "tahrîf" in the sense of Jewish and Christian interpretation when they understand their own scriptures, while the text is undoubtedly true by nature. According to al-Ṭabarî himself, as quoted by al-Qasîmî that the word "yuharrifûnahu" means they exchange meaning and interpretation, and change it (Sirry 2013, 170).

Regardless of these myths and issues, the scriptures that were revealed before the Quran in the historical narrative are a continuation of the earlier divine revelation of what is known as the term Suhuf Ibrâhîm. In the Quran, the term is explicitly included at the end of the Surah al-A'lâ. Moqsith Ghazali refers to the book of al-Jâmi' li Ahkâm al-Qur'ân by al- 
Qurțubî based on the riwâyat of Abû Dhar saying that the book passed down to the Prophet Ibrâhîm (Suhuf Ibrâhîm) contains the details of life, both worldly life and the hereafter (Ghazali, 122).

Rusydi al-Badrawi said, based on the hadith conveyed by Abu Dhar, that the Prophet Ibrâhîm received ten Suhuf. The Suhuf contains about faith in Allah, orders for people to manage worldly life and interactions, orders to better their morals, and the orders to establish an ideal family e.g. the obligation to treat parents well, being gentle to partner, and educating children. In Islamic law, Suhuf Ibrâhîm contains inheritance law, caring for poor people, prohibition on stealing, usury, adultery, killing, and sanctions for the doers (Harahap 2013, 85-86).

Generally, the universal principals of the sharia purpose itself, as known in sharia law literature, are the protection on religious freedom, mind, ownership, family/ancestry/ and honor. Hence, in the context of these universal principles, the Quran and previous books find a common ground. They have the same goal of ensuring human's safety and happiness. In addition, they are the words of God revealed to humans although not at the same time.

\section{Conclusion}

In essence, the disbelievers disagree with the meaning of the position of the Quran as al-Muhaymin. The significance of the Quran as alMuhaymin over the previous book is, among other things, a "standard". alMuhaymin is considered as a standard because the Quran is the last book. The position of the Quran as al-Muhaymin has a relation to other religious scriptures because the earlier books were a guide for the religious community such as the Bible being the Christian's scriptures. The relationship of the Quran and other scriptures is as the sharia that God has revealed to people and the universal principles of the teachings.

\section{References}

al-Adib, Ahmad Nur kholis. 2013. Quran Karim Dan Terjemah Artinya. Trans. Zaini Dahlan. Yogyakarta: UII Prees. 
Affandy, Sa'dullah. 2015. Menyoal Status Agama-Agama Pra-Islam; Kajian Tafsir Alquran Atas Keabsahan Agama Yahudi dan Nasrani Setelah Kedatangan Islam. Bandung: Mizan.

Amaliyah, Amaliyah. 2017 "Satu Tuhan Tiga Agama (Yahudi, Nasrani, Islamdi Yerusalem)." Religious: Jurnal Agama Dan Lintas Budaya 1(2): 185-90.

DOI: https://doi.org/10.15575/rjsalb.v1i2.1395

Anwar, Hamdani. 2016. "Tahrif dalam Al-Qur'an: Studi Analitis tentang Perubahan yang Bersifat Lafdzy dan Ma'nawy.” Misykat: Jurnal IlmuIlmu Al-Qur'an, Hadist, Syariah dan Tarbiyah 1(1): 49-74.

DOI: http://dx.doi.org/10.33511/misykat.v1n1.49

Al-A'zami, M.M. 2005. Sejarah Teks al-Qur'an Dari Wahyu Sampai Kompilasi: Kajian Perbandingan dengan Perjanjian Lama dan Perjanjian Baru. Jakarta: Gema Insani.

Aziz, Moh. Ali. 2015. Mengenal Tuntas Alquran. Surabaya: Imtiyaz.

Departemen Agama Republik Indonesia. 2009 Alquran Dan Terjemahnya. Bandung: Syamil Quran.

Donner, Fred M. 2015 Muhammad Dan Umat Beriman. Trans. Syafaatun Almirzanah. Jakarta: PT Gramedia Pustaka Utama.

Firdaus, Salsabila. 2015. “Al-Sidq Dalam Al-Qur'an.” Undergraduate Thesis. Universitas Islam Negeri Sunan Kalijaga Yogyakarta.

Ghazali, Abd. Moqsith. 2009 Argumen Pluralitas Agama: Membangun Toleransi Berbasis Al-Qur'an. Depok: KataKita.

al-Ghazali, Muhammad. 2004. Tafsir Al-Ghazali. Trans. Safir Al-Azhar. Yogyakarta: Penerbit Islamika.

al-Ghurnâtî, Athîr al-Dîn Muhammad ibn Yûsuf Abû Hayyân al-Andalûsî. 2010. Tafsîr al-Baḥr al-Muhît. Beirut: Dâr al-Kutub al-'Ilmiyah.

Haif. Abu. 2004. "Perjanjian Hudaibiyah (Cermin Kepiawaian Nabi Muhammad saw. Dalam Berdiplomasi).” Rihlah: Jurnal Sejarah dan Kebudayaan 1(2): 119-31.

DOI: https://doi.org/10.24252/rihlah.v1i01.673 
Halim, Ilim Abul. 2017 "Agama Yahudi Sebagai Fakta Sejarah Dan Sosial Keagamaan.” Religious: Jurnal Agama Dan Lintas Budaya 1(2): 13546.

DOI: https://doi.org/10.15575/rjsalb.v1i2.1392

Harahap, Iqbal. 2013. Ibrahim a.s. Bapak Semua Agama: Sebuah Rekonstruksi Sejarah Kenabian Ibrahin a.s. sebagaimana Tertuang dalam Taurat, Injil, dan Al-Qur'an. Tangerang: Lentera Hati.

Hitti, Philip K. 2013. History Of The Arabs. Trans. R. Cecep Lukman Yasin and Dedi Slamet Riyadi. Jakarta: Serambi.

Ibn Kathîr, Abû al-Fidâ’ Ismâ'îl ibn 'Umar. 2000. Tafsîr al-Qur'ân al-Ažim. Cairo: Maktabah Awlâd al-Shaykh li al-Turâth.

Ismatulloh, A.M. 2012 "Konsepsi Ibnu Jarir Al-Tabari Tentang Alquran, Tafsir Dan Ta'wil." Fenomena: Jurnal Penelitian 4(2): 203-19.

DOI: https://doi.org/10.21093/fj.v4i2.224

Khalil, Mohammad Hassan. 2016. Islam Dan Keselamatn Pemeluk Agama Lain. Trans. Chandra Utama. Bandung: Mizan

Labib, Rohmat S. 2013. Tafsir Ayat Pilihan Al-Wa'ie. Bogor: Al-Azhar Freshzone Publishing.

Lasmana, Nunung, and Ahmad Suhendra. 2017. "Al-Qur'an dan Tiga Kitab Suci Agama Lain.” Jurnal Asy-Syukriyah 18(1): 39-52.

DOI: https://doi.org/10.36769/asy.v18i1.70

Madjid, Nurcholish. 2005. Islam Doktrin Dan Peradaban. Jakarta: Paramadina.

al-Mahallî, Jalâl al-Dîn and Jalâl al-Dîn al-Suyûțî. n.d. Tafsîr al-Qur'ân alAžîm. Surabaya: Maktabah Dâr al-Jawâhir.

Makin, Al. 2016. Keragaman Dan Perbedaan; Budaya Dan Agama Dalam Lintas Sejarah Manusia. Yogyakarta: Suka-Press.

al-Marâghî, Aḥmad Musțafâ. 1946. Tafsîr al-Marâghî. Cairo: Musțafâ al-Bâbî al-Ḥalabî,

Mukzizatin, Siti. 2019. "Relasi Harmonis Antar Umat Beragama dalam AlQur'an." Andragogi Jurnal Diklat Teknis Pendidikan dan Keagamaan 7(1): $161-80$. 
DOI: https://doi.org/10.36052/andragogi.v7i1.75

An-Nabhani Taqiyuddin. 2007. Mafahim Hizbut Tahrir. Trans. Abdullah. Jakarta: Hizbut Tahrir Indonesia.

al-Qurțubî, Abû 'Abd Allâh Muhamamad ibn Aḥmad. n.d. al-Jâmi' li Aḥkâm al-Qur'ân. Beirut: Mu'assasah al-Risâlah.

al-Râzî, Fakhr al-Dîn. 1999. Mafâtih Ghayb. Beirut: Dâr al-Ihyyâ al-Turâth.

al-Samarqandî, Abû al-Layth. 1993. Tafsîr al-Samarqandî al-Musammâ Bahr al'Ulûm. Beirut: Dâr al-Kutub al-'Ilmiyyah.

Shihab, M. Quraish. Tafsir Al-Misbah: Pesan, Kesan Dan Keserasian Alquran. Jakarta: Lentera Hati.

Sirry, Mun'im. 2013. Polemik Kitab Suci; Tafsir reformis Atas Kritik Alquran Terhadap Agama Lain R. Cecep Lukman Hakim. Jakarta: Gramedia Pustaka Utama.

Sulaiman, Tasirun. 2011. Al-Qur'an Berbicara Agama Lain: Sisi Keterbukaan Kitab Suci Umat Islam. Jakarta: Dian Rakyat.

al-Ṭabarî, Ibn Jarîr. 2001. Jâmi' al-Bayân 'an Ta'wîl 'Ây al-Qur'ân. Egypt: Dâr al-Hadith.

al-Tha'labî, Ahmmad ibn Muhammad. 1997. Tafsîr al-Tha'labî al-Musammâ Jawâhir al-Hisân fì Tafsîr al-Qur'ân. Beirut: Dâr al-Ihyyâ al-Turâth al'Arabî.

al-Ṭ̂usî, Nasîr al-Dîn. n.d. al-Tibyân fî Tafsîr al-Qur'ân. Beirut: Dâr al-Ihyâ alTurâth al-Arabî.

Mahmud Syaltut. 1999. Tafsir Alquran Al-Karim. Trans. Herry Noer Ali. Bandung: CV. Diponegoro.

Ubaidah, Darwis Abu. 2012 Tafsir Al-Asas. Jakarta: Pustaka Al-Kautsar.

al-Zarqânî, Muhammad 'Abd al-'Aẓîm. 2002. Manâhil al-'Irfân fî̀ 'Ulûm alQur'ân. Trans. M. Qadirun Nur and Ahmad Musyafiq. Jakarta: Gaya Media Pratama.

al-Zuhaylî, Wahbah. n.d. Tafsîr al-Wajı̂z. Damascus: Dâr al-Fikr.

Zuhri, H. 2013. Pengantar Studi Tauhid. Yogyakarta: Suka Press. 